\title{
LA CODIFICACIÓN DEL RELATO MÍTICO EN EL ARTE DEL PALEOLÍTICO SUPERIOR
}

\section{THE MYTHICAL STORY CODING UPPER PALAEOLITHIC ART}

\author{
RAQUEL LACALLE RODRÍGUEZ
}

\begin{abstract}
Resumen: El arte paleolítico es un registro de conceptos, mitos y actos rituales. Es objetivo de este estudio tratar de interrelacionar las formas en que se manifiesta el lenguaje iconográfico con los relatos míticos a los que alude.

Palabras claves: Arte paleolítico. Lenguaje iconográfico. Mitos y rituales.
\end{abstract}

\section{DEFINICIÓN DE CONCEPTOS}

El santuario paleolítico es el contexto donde se efectuaron rituales, escenificaciones probables de hechos míticos. Buena parte del arte paleolítico se hace eco de estos mitos y rituales. En las paredes de las cavernas-santuarios y en los objetos de arte mueble se hallan plasmados conceptos y hechos míticos, siendo labor del prehistoriador su descodificación.

Las teorías de la magia de la caza, aplicadas al arte (Breuil 1952: 23-24; Reinach 1905: 125-136), consideraron que las pinturas paleolíticas poseían un sentido mágico para propiciar la caza y facilitar su multiplicación. Los paneles decorados eran el resultado de la acumulación a lo largo del tiempo de figuras independientes unas de otras y, por tanto, carentes de coordinación y de organización. Estas primeras teorías entendían que lo significativo era la imagen aislada, como acto mágico en sí mismo; la superposición evidenciaba una serie de actos acumulados en el tiempo. Esta concepción del arte fue criticada a partir de los estudios de Laming-Emperaire y Leroi-Gourhan,

\begin{abstract}
Palaeolithic Art is a record of concepts, myths and rites. It's our objective to marry the different ways in which iconographycal language appears with the mythic stories related by art.

Key words: Palaeolithic Art. Iconographycal language. Myths and rites.
\end{abstract}

los cuales plantearon el carácter no aleatorio de las figuras animadas y de los conjuntos (Leroi-Gourhan 1984a: 530-531; Laming-Emperaire 1962). Ambos autores mantienen que las agrupaciones y superposiciones de figuras no tienen por qué implicar siempre un sentido cronológico (Leroi-Gourhan 1968: 117), obedecerían a un sentido compositivo, a la forma en la que el hombre paleolítico correlaciona los temas. En el caso de las superposiciones, las asociaciones significativas se sitúan en distintos planos. Constatan la asociación frecuente de ciertos temas, animales y signos, lo cual les lleva a pensar en una ordenación binaria de los temas: dos temas acoplados o yuxtapuestos, cuya repetición reproduciría un sistema dual.

Para Leroi-Gourhan (1968: 97-99), las figuras parietales no serían el mero resultado de la adición repetida de elementos aislados. Las asociaciones figurativas serían intencionales y responderían a una decoración de las cuevas según un plan sistemático y a una organización de las cuevas en santuarios, cuya decoración se encontraría organizada, procediendo a través de composiciones repetidas, separadas por zonas de transición. 
Bien sea que las figuraciones hayan sido hechas sincrónicamente, ya se hayan ejecutado en cortos intervalos, o en el caso de que su asociación se haya producido en el curso de los siglos, las figuras parietales mantienen una solidaridad entre sí.

Admitiendo que el mensaje transmitido a través del arte paleolítico se estructura a partir de la agrupación intencional de los temas, conviene trazar líneas sobre la definición del tipo de mensaje emitido y el sistema de transmisión del mensaje utilizado. Sobre estas cuestiones traemos a colación la clasificación y definición de estas cuestiones, establecida por Leroi-Gourhan. Este autor precisó diferencias entre varios conceptos: mitograma, pictograma e ideograma. El concepto de ideograma comprende aquellas imágenes que representan una idea o un ser, un concepto. El mitograma hace alusión a hechos o relatos míticos. Leroi-Gourhan utiliza en algunos casos el concepto de ideograma, pero suele preferir la denominación de mitograma, de modo genérico, en cuanto al empleo de figuras animales en el arte paleolítico, reservando el uso del concepto de pictograma para aquellas representaciones que pueden catalogarse como escenas, con un sentido descriptivo de una acción.

En líneas generales este autor hace una distinción entre el modelo mitográfico y el pictográfico. Los conjuntos de figuras pueden presentar dos formas de expresión que pueden combinarse, pero que responden a modelos figurativos distintos. En el primero no se hace referencia al tiempo de forma explícita. Las figuras agrupadas no presentan otro vínculo entre ellas que el ritmo de la composición, ni otra animación que la que pueda transmitirse a partir de la recitación del narrador. Propuso que se denominase mitográfico a este modo de expresión que ofrece relaciones con representaciones míticas en las que el tiempo ha quedado de alguna manera fuera de la representación (Leroi-Gourhan 1984a: 608-609). Los conjuntos de figuras animales, signos o representaciones humanas sobre las paredes de las cavernas se situarían a primera vista en la categoría de los mitogramas, puesto que aparecen constituidos por figuras agrupadas sin linearidad, es decir, por temas simbólicos cuyo encadenamiento corre a cargo del comentador (Leroi-Gourhan 1984a: 531). En los tiempos históricos la traducción espacial del desenvolvimiento de una acción llevaría del mitograma al pictograma y a diversas formas de linearización de los signos que son características de la escritura.

El modo de expresión pictográfico introduce entre las figuras la trama de una acción, sugiriendo un pasado y un futuro, una acción inscrita en la dimensión temporal. Diferencia por un lado lo que él denomina el pictograma (Leroi-Gourhan 1984a: 532), que se referiría a una figura o conjunto de figuras que llevan a cabo una acción, diferenciándolo de la continuación pictográfica, cuando se trata de un conjunto de pictogramas linearizados que traducen los momentos sucesivos de una secuencia operativa. En su conjunto, interpreta que el arte paleolítico ofrece muchas más asociaciones de figuras en orden mitográfico que en disposición pictográfica, pero el mitograma pudo traducir pictográficamente ciertos elementos del mensaje. Mitograma y pictograma tendrían desde el Paleolítico fronteras permeables. Se basa en que numerosos conjuntos en una primera impresión parecen ser un conjunto de elementos inanimados, sostenidos únicamente por el ritmo de su disposición espacial, existiendo en éstos un número generalmente restringido de figuras que han sido objeto de una animación que termina en una verdadera pictografía. Considera la llamada "escena del pozo de Lascaux" o el bloque esculpido de Roc-de-Sers, con el bisonte atacando a un hombre, ejemplos de pictogramas. Las figuras inanimadas serían, por tanto, numéricamente dominantes y sólo una minoría de figuras adoptarían la moda pictográfica (Leroi-Gourhan 1984a: 534).

El mitograma se definiría, por tanto, como un enunciado (Leroi-Gourhan 1984a: 531) de símbolos sostenidos por el ritmo de su disposición plástica. Las imágenes se yuxtaponen o se superponen, pero no se articulan de manera narrativa, por lo que se hace particularmente difícil poner en evidencia su organización. Un aspecto de la mentalidad paleolítica lo constituiría la repetición del mitograma en diferentes planos y a distancias variables. Este hecho hace que el mismo tema vuelva a aparecer diversas veces en la misma cavidad: en Les Combarelles, la díada caballo-bisonte o caballo-toro, con reno o mamut como complementarios ocupan los paneles mediante asociaciones sucesivas.

\section{LAS FORMAS Y CONTENIDOS DEL MENSAJE}

A partir de estas definiciones establecidas por LeroiGourhan, que consideramos introductorias para el estudio de esta problemática, conviene ahora analizar algunos ejemplos en el arte paleolítico que muestren las diversas formas de transmisión de los mensajes. Puede resultar clarificador analizar los diversos mecanismos empleados en la codificación de los mensajes, abordando al mismo tiempo los contenidos evocados. Para llevar a cabo su interpretación creemos oportuno plantear como algo viable el utilizar como clave de lectura 
la mitología luni-solar. Pretendemos mostrar a lo largo de este artículo cómo los elementos que constituyen el arte paleolítico, muchos de ellos constatados por LeroiGourhan y Laming-Emperaire, pueden obtener un sentido y lógica al contemplarlos desde estos parámetros explicativos. Planteamos, por tanto, la posibilidad y viabilidad de esta lectura alternativa, frente a otras que han sido expuestas a lo largo del desarrollo de las investigaciones. Creemos que debe tenerse en cuenta, puesto que además de otorgar una coherencia interpretativa, este tipo de lectura puede fundamentarse en datos extraídos del fondo común temático de diversas mitologías.

\section{El tema solar y lunar}

Buena parte de las interpretaciones en torno al arte paleolítico se centraron en atribuirle un carácter realista con fines materiales: la obtención de la caza a partir de su reproducción artística con fines mágicos. Se identificaba, por tanto, el objeto que veíamos a primera vista con el mensaje transmitido por el autor. Se pensaba que una parte de la cultura de grupos de tipo cazadores-recolectores, la que se refiere a las actividades mágicas y a la preocupación por su sustento, formaba globalmente el universo mental de los cazadores-recolectores paleolíticos, como si todo su sistema de creencias quedara reducido al afán por obtener las piezas deseadas de caza. Se tomó la parte por el todo. Desde esta perspectiva, los animales no podían ser otra cosa que los animales que se encontraban en su entorno y deseaban cazar.

Optamos desde aquí, en cambio, por una interpretación de tipo simbólico, más acorde con el sentido de los mitos y los ritos y con el papel desempeñado por los zoomorfos representados en el arte paleolítico en diversas culturas. Las sociedades de cazadores-recolectores además de actividades mágicas poseen espíritus superiores o divinidades, a las que invocan en sus prácticas de tipo mágico. Los grupos cazadores tienen importantes conocimientos astronómicos $\mathrm{y}$, con frecuencia, el sol o la luna son sus divinidades y dirigen a ellas sus ceremonias. Podemos citar, por ejemplo, a los selknam (Catalán 2006) o a los indios de las praderas (Lowie 1983: 25-48). La forma en que se plasman las divinidades adopta con frecuencia la morfología animal.

La mitología lunisolar ha dejado una importante impronta en los diversos sistemas de creencias. Los acontecimientos principalmente enunciados en los mitos son habitualmente expresados a través de fórmulas bastante estereotipadas en las diferentes culturas, las cuales pueden fácilmente hacerse corresponder con los elementos característicos del arte paleolítico, sobre todo con el sistema dual señalado por Leroi-Gourhan y Laming-Emperaire, en torno a las figuras del bisonte y el caballo. De esta forma, si tenemos en cuenta la información que obtenemos a partir de que poseemos fuentes escritas y a través de la documentación etnográfica, sabemos que los animales que caracterizan el repertorio temático del arte paleolítico han sido utilizados con frecuencia como atributos y emblemas lunisolares, apuntando claramente hacia el arte del Paleolítico Superior como cuna de estos símbolos. El toro se ha asociado a la luna en el ámbito mediterráneo. El ciervo aparece figurado en el arte postpaleolítico de la Península Ibérica junto a figuraciones solares. El caballo ha estado vinculado al sol en poblaciones eslavas, nórdicas, hindúes, griegas... El oso se vincula con la luna, la noche y el invierno en las tradiciones árticas y siberianas.

Por tanto, mediante una aplicación de los sucesos y elementos míticos característicos de los sistemas de creencias lunisolares, puede resultar fácil la descodificación de muchos de los elementos del arte paleolítico (Lacalle 1996; 1998). Aplicando esta "clave" interpretativa podemos analizar tanto los métodos de los que se sirvió nuestro antepasado paleolítico para cifrar la información, como el contenido de estos mensajes. En líneas generales, pensamos que el arte paleolítico es de carácter simbólico, es decir, que las imágenes a través de las que se expresa evocarían conceptos de un sentido diferente a lo que la imagen en primera instancia transmite. Estos conceptos serían evocados, bien por alguna semejanza o por algún tipo de conexión o correspondencia existente.

Las razones que explicarían el uso de este tipo de mecanismos para cifrar la información residirían en el cariz iniciático y secreto del arte, un sentido oculto que no se manifiesta de forma inmediata (Hauser 1982: 53$54,105,109)$. El acceso a sus contenidos se canalizaría a través de los grados de iniciación chamánicos. De manera que podemos decir que las formas propias del mundo de la caza podrían ser usadas como vehículo para la transmisión de otro tipo de conocimientos más "trascendentes".

El establecimiento del campo semántico en el que nos vamos a mover para efectuar una lectura del arte paleolítico nos puede permitir precisar la adecuación de los conceptos anteriormente expuestos, teniendo en consideración los aspectos significativos del arte paleolítico. Desde esta perspectiva, sería adecuado hacer algunos comentarios en torno a la denominación de los medios de expresión utilizados por el hombre paleolítico cuando transmite ideas a través de las manifestaciones artísticas, que complementen a las anteriormente enunciadas, expresadas por Leroi-Gourhan. Al menos, 
nos parece conveniente abordar los argumentos que se pueden tener en consideración para establecer una discusión sobre el tema.

Este autor, como hemos visto, muestra su predilección por el concepto de mitograma aplicado a las figuraciones zoomorfas e ideograma para los elementos más esquemáticos y abstractos. Sin embargo, otros autores prefieren usar el concepto de pictograma, de forma genérica, por el hecho de que este primitivo sistema de comunicación, que es el arte paleolítico, está constituido en su aspecto más sustancial por elementos figurativos y pictóricos. Sobre este último planteamiento, se pueden hacer los siguientes cuestionamientos. La palabra pictograma denota una atención a los aspectos formales, descriptivos y artísticos de los elementos que, en este caso, constituyen el sistema de comunicación. Pero si atendemos más a su estructuración interna, al tipo de mensaje codificado, se abre un abismo, en lo que respecta a lo que habitualmente se suele considerar como pictograma, puesto que una cosa es que el sistema opte por expresarse en forma pictórica y otra es el mecanismo y el tipo de transmisión del mensaje que se efectúa. Desde este punto de vista, de una concepción del mensaje diferente a la realidad material transmitida en una primera lectura, nos parece más adecuado calificar, de forma genérica, a los elementos constituyentes de las manifestaciones artísticas paleolíticas como ideogramas, puesto que se trataría de imágenes o símbolos que significan otra idea o ser, distinto del que evocan directamente, y que a su vez podrían dividirse en figurativos y abstractos (ideomorfos). El uso del ideograma responde a una concepción del lenguaje artístico de corte muy diferente a aquellas tradiciones que se basan en el uso del pictograma. En el segundo predomina lo descriptivo, lo real; en el primero lo analítico, lo sustitutivo e ideal. No es lo mismo expresar que una persona efectúa un viaje a las montañas, y plasmarlo de forma pictórica, que transmitir un mensaje de orden diferente y expresarlo a través de imágenes, cuyo enlace con el mensaje es difícil de detectar en primera instancia, como creemos es el caso del arte paleolítico.

En este sentido, dentro de la terminología habitualmente manejada, nos parecen más adecuados los términos ideograma y mitograma, dejando el concepto de pictograma para aquellos casos de figuras o conjuntos de éstas en las que explícitamente se describe una acción y en las que ésta es determinante en la fijación del significado, o bien, en aquellos casos en los que se hace alusión a hechos rituales. No obstante, aunque mostremos aquí nuestra opción por una determinada nomenclatura, el tema en sí de la terminología usada para la definición del sistema de comunicación pictórico usado en el Paleolítico Superior genera un amplio debate y está abierto a la discusión. El arte paleolítico no tiene una finalidad exclusivamente estética, como en nuestros días, ante todo es utilizado como medio de codificación y fijación de conceptos y acontecimientos, relacionados con el mundo mítico y ritual.

A través de la figura del caballo, el hombre paleolítico pudo transmitir la idea del sol o el verano, así como mediante la figura del toro identificar a la luna o al invierno. A través de detalles y acciones que desarrollan los elementos figurativos se transmitirían otros contenidos de forma alegórica. Analicemos algunos ejemplos que nos permitan comprender un poco más, tanto los contenidos, como los modos de transmisión del mensaje utilizados por el hombre paleolítico cuando codifica conceptos y relatos míticos, y que pueden ser entendidos bajo este enfoque.

En las mitologías, la luna suele ser considerada como un ser andrógino, a partir de la variabilidad de sus fases, presentando aspectos masculinos y femeninos. $\mathrm{Su}$ aspecto menguante es relacionado con lo masculino, mientras que el aspecto circular lo señala como luna grávida femenina. De ahí su concepción como ser andrógino, por reunir aspectos masculinos y femeninos. Este tipo de conceptos podrían encontrar correlaciones en ciertos objetos y representaciones, donde Leroi-Gourhan advertía la combinación de formas masculinas y femeninas.

Una conjunción de los dos principios opuestos se puede observar en el ideograma paleolítico señalado por Leroi-Gourhan, formado por el cuerno del bisonteojo de bisonte (Fig. 1). Por un lado el ojo o el óvalo representarían a la vulva y el cuerno al falo (Leroi-Gourhan 1968: 31). Estas cuestiones quedarían completadas y adquirirían un pleno sentido al ser contempladas desde el lenguaje mítico astral. El ideograma evocaría el concepto de androginia de la divinidad que reúne aspectos femeninos (lo lleno, lo redondo, grávido) y los masculinos (el menguante, lo fálico). El cuerno designa el aspecto masculino, fálico de la luna, y el ojo, la luna llena, el principio femenino. Se utiliza la metáfora de la unión genital como referencia de la unicidad de principios que presenta la divinidad lunar.

Tomando como ejemplo los bastones perforados, podemos ver que suelen adoptar una morfología masculina, en especial en algunos ejemplares, destacando en ellos el orificio. Algunos son denominados "bastones machos" por el hecho de tener esculpido en uno de sus extremos un volumen similar al glande, como ocurre en los ejemplares de El Pendo o El Valle. En cualquier caso, en los bastones destaca la morfología 


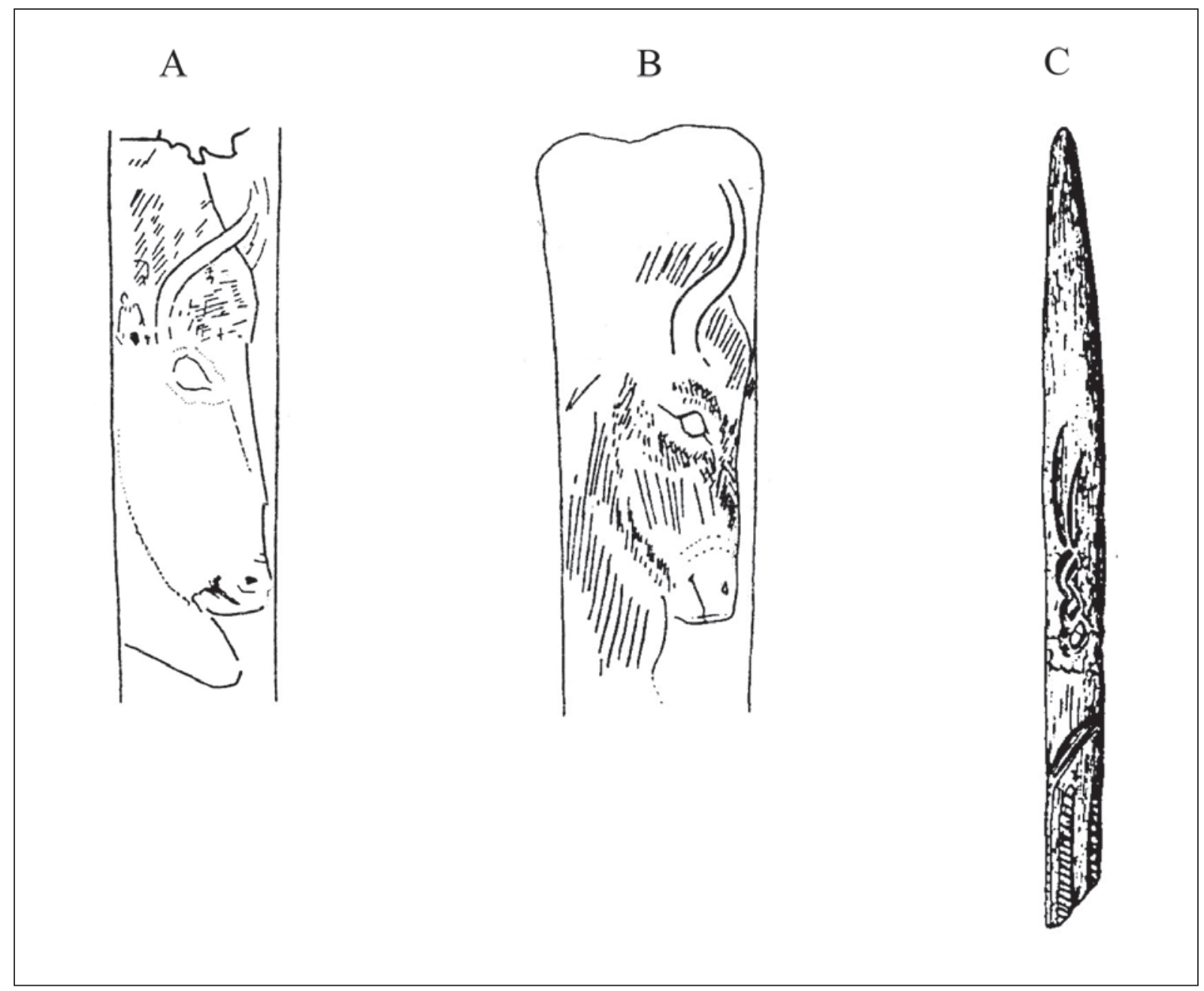

Figura 1. El ideograma ojo-cuerno. A-B. Fragmentos de bastones perforados con cabezas de bisonte grabadas de la cueva de Isturitz (Bajos Pirineos, Francia) (Según J.L. Ibarra); C. Varilla de La Vache (Ariège) con esquematización del ojo-cuernos (Según Breuil y Robert).

alargada, que puede considerarse masculina, en combinación con el orificio, de forma similar a lo que se podría observar en la decoración de las varillas y bastones con el tema: cuerno-ojo. Es decir, idéntica combinación es reproducida ahora en la misma morfología del soporte. De hecho, Leroi-Gourhan no excluía que el agujero del bastón perforado tuviera un sentido femenino y que tal aspecto estaría vinculado al principio general de las figuras sexuales yuxtapuestas (Leroi-Gourhan 1968: 26). Mediante este emparejamiento se correlaciona la siguiente constelación de significados: cuerno-falo-creciente-menguante lunar junto al círculo-vulva-luna llena. A través de la morfología se evoca el concepto de androginia de la divinidad lunar. A su vez, estos bastones suelen estar decorados, de manera que la decoración parece tener en cuenta la morfología del orificio (Fig. 2-5). Vemos así que en el arte paleolítico, con frecuencia, prótomos o figuras animales anteceden a las formas circulares de los orificios en los objetos. La disposición que adoptan apunta a que poseyeron algún tipo de significación.

En los ejemplares de El Castillo, Cualventi o Les Hoteaux (Fig. 2 y 3), la figura del ciervo se ha colocado delante del orificio. Se pueden citar otros ejemplos, en los que el orificio del objeto desempeña una función en el mensaje que se desea transmitir. En un bastón del abrigo de La Madeleine (Dordoña), se dispusieron cuatro caballos en fila, figurando entre ellos el orificio. La otra cara se decoró con tres caballos en fila. Reconocemos aquí el tema solar en su recorrido de 3 ó 4 etapas y 


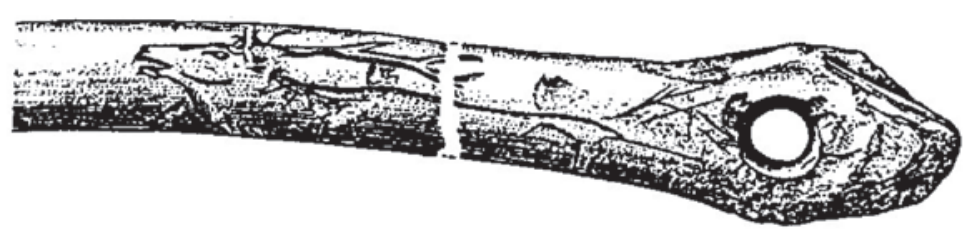

Figura 2. Bastón perforado de Les Hoteaux (Ain) (en Sanchidrián 2005).
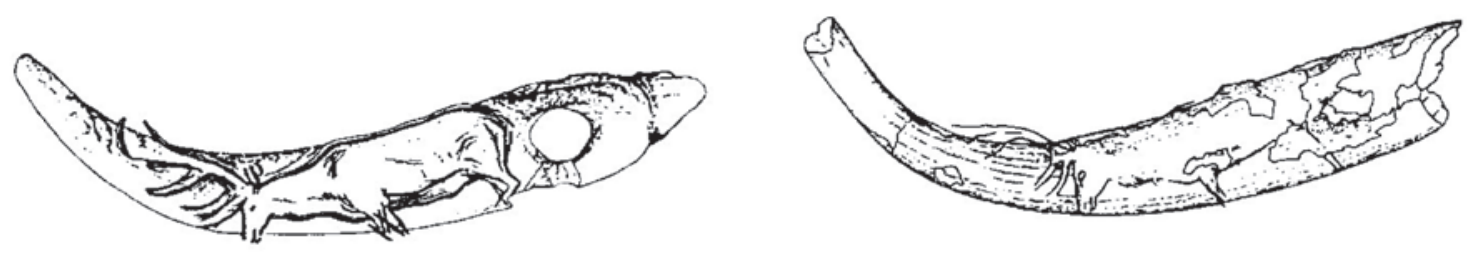

Figura 3. Bastones perforados del Magdaleniense Superior: El Castillo y Cualventi, Cantabria (Según I. Barandiarán).
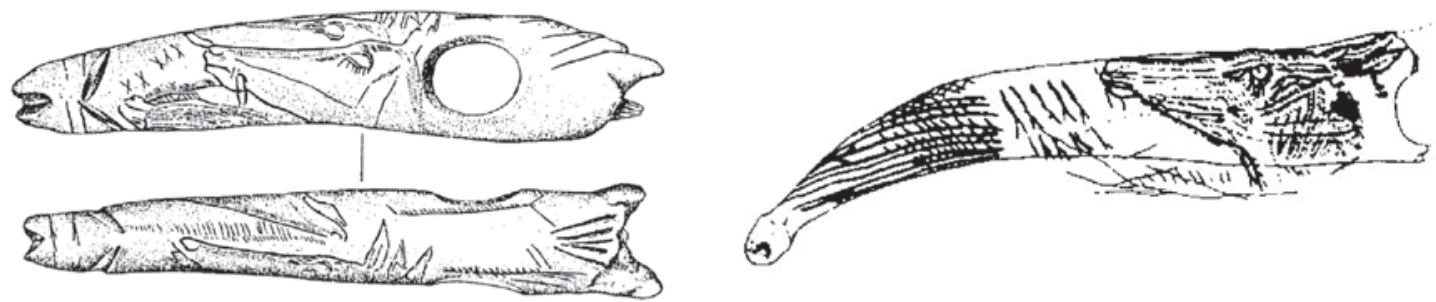

A

B

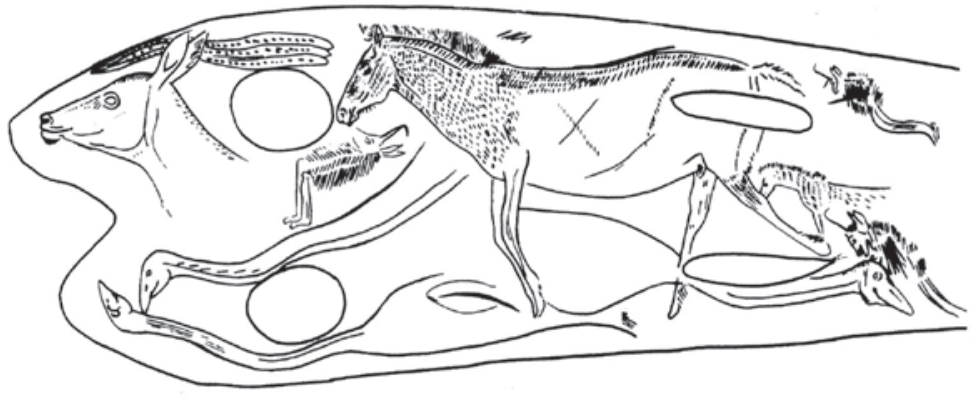

$\mathrm{C}$

Figura 4. Bastones perforados con el tema de la cierva y el orificio: A. El Pendo (Cantabria) (Según I. Barandiarán); B. El Valle (Cantabria) (Según I. Barandiarán); C. Abrigo Mège (Teyjat, Dordoña, Francia) (Según H. Breuil y R. de Saint-Périer). 


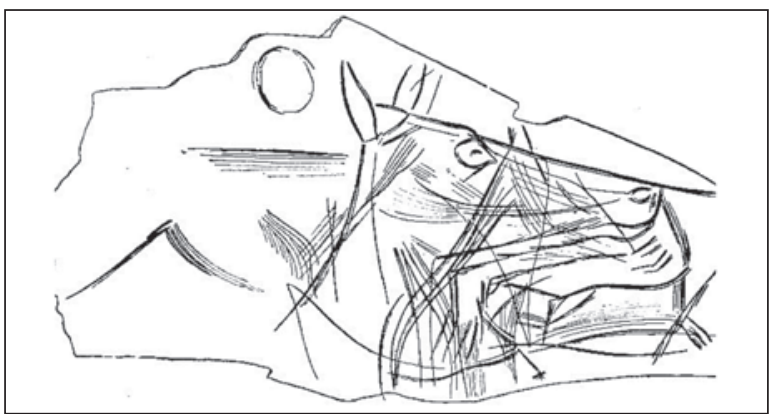

Figura 5. Omóplato con cabezas de ciervas de El Castillo (Puente Viesgo, Cantabria, España). La cierva es repetida cinco veces, indicando el movimiento de la cabeza. Magdaleniense Antiguo (Según H. Breuil).

en el que el orificio juega una importante función significativa en la definición y plasmación del tema. Los cuatro caballos de una cara aluden a las cuatro direcciones del sol y a las cuatro estaciones. Los tres caballos de la otra cara se refieren al recorrido diario del sol, su nacimiento, plenitud en el cenit y su declive u ocaso. El papel de los zoomorfos, en estos casos, respondería a su uso como vehículo de otros conceptos, como el sol, el sol naciente o poniente, el verano, la luna, luna nueva, luna-andrógina, el invierno...

En los casos de los bastones de El Pendo y Valle (Fig. 4a y 4b) se disponen cabezas de ciervas delante del orificio. Esto mismo ocurre en el omóplato con cabezas de ciervas de El Castillo (Fig. 5). En el caso de El Pendo (Cabrera y Jiménez 1989), además, en el bastón aparece una cabeza de ciervo y otra de caballo. El tema de la cierva precediendo a un caballo y al orificio lo podemos apreciar en el bastón perforado sobre asta de cérvido del abrigo Mège, Teyjat (Fig. 4c) (Barandiarán 2003: 99-101), del Magdaleniense Superior. Parece tratarse de un concepto fijado y no una disposición aleatoria. Por el contrario, se trata de una colocación intencionada de la cabeza de la cierva precediendo al círculo o al caballo. En otras ocasiones, tanto en el arte parietal como mobiliar, se constata el tema de la cierva precediendo al ciervo como ocurre en una placa de piedra del Solutrense Inferior de El Parpalló (Gandía, Valencia) o en un bastón perforado de La Madeleine (Dordoña) (Fig. 6), del Magdaleniense Superior (Barandiarán 2003: 84-86). El orificio, además de su función, posee un significado, colocado tras las cabezas de las ciervas. Puede ser una alusión al círculo, en este caso, adquiriendo una significación solar, en relación a la figura de la cierva.

En el caso del bastón perforado de Teyjat, la disposición y enlace de elementos artísticos es entendible en el plano simbólico (cierva, caballo, serpentiformes). No existe una conexión real entre los elementos yuxtapuestos, su conexión es ideal. Los distintos elementos se leerían en niveles distintos. Así, la idea expresada puede referirse al hecho diario del nacimiento solar al amanecer, pero al mismo tiempo significar, a nivel anual y estacional, la aparición de la temporada cálida con la llegada de la primavera. Del mismo modo, puede significar un concepto más general: la idea de la renovación, implícita en el emblema serpentiforme. Estos conceptos pueden ser expresados a través de una forma mítica, por lo cual, entonces estaríamos ante la codificación de un mito, un mitograma. Se conocen relatos míticos de cazadores como los blackfoot que se refieren a la estrella matutina. Entre los pawnees, la estrella matutina y la vespertina tenían un importante papel (Zimmerman 2003: 35). El relato maya de la primera aurora describe a las primeras personas creadas, los fundadores de los cuatro linajes quichés, que espiaron a Venus, al salir antes que el Sol. Quemaron incienso copal hacia el este en dirección al sol naciente. Cuando el humo ascendió al cielo esperaron al alba. Cuando salió el sol todos los animales del mundo se reunieron en las cimas de las montañas y dirigieron su mirada al este.

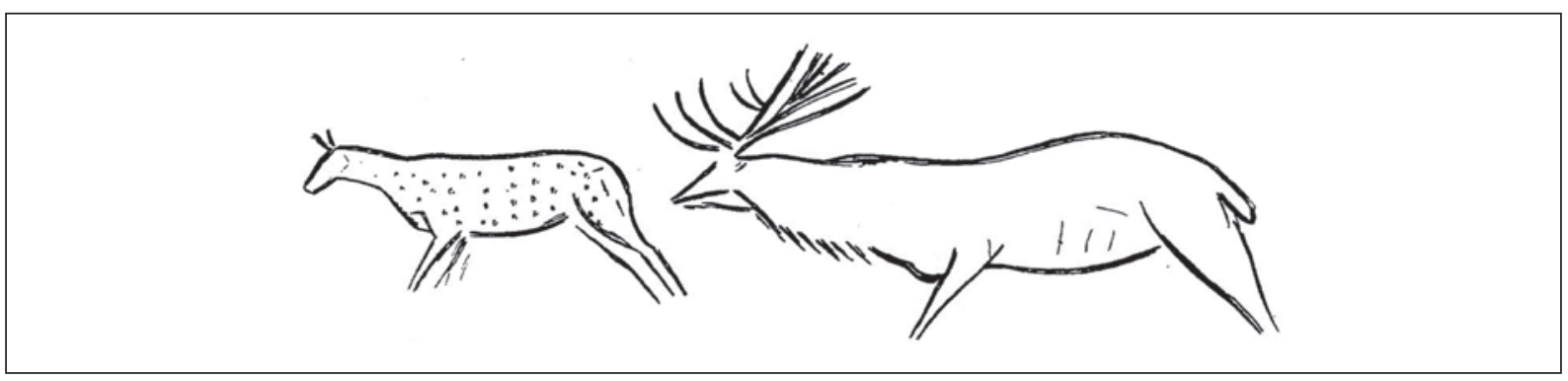

Figura 6. Fragmento de bastón de asta del abrigo de La Madeleine (Tursac, Dordoña, Francia) con dos figuras grabadas de una cierva y un ciervo (Según H. Breuil). 
En el caso del bastón de La Madeleine, su definición en cuanto a la forma escogida de codificación del mensaje es más difícil, dado su carácter descriptivo de una acción real. Se vale de acciones y detalles extraídos de la realidad para trasladar, en nuestra opinión, un mensaje de corte alegórico. Es una escena en la que un ciervo persigue a una cierva, por lo que podría en primera instancia considerarse como un pictograma. Pero hay que tener en cuenta que el tema está bien definido a nivel iconográfico, con lo cual apunta hacia su consideración como un tema de orden mítico. En este caso, debemos tener en cuenta que su lectura puede trascender a la realidad inmediata descrita y ser evocadora de otro tipo de hechos que paralelizarían al acto real de persecución del ciervo a la cierva. En el contexto significativo que estamos analizando la idea mítica que se presenta como más viable es: el sol siguiendo a Venus (Müller 1988: 81-84). Las escenas descriptivas pueden entrañar un mensaje en forma metafórica. Se ha interpretado la supuesta "escena" como un acto de preacoplamiento (Barandiarán 2003: 84-87) en la época de apareamiento. De ser así, se deduciría implícitamente una información estacional, el final del verano y el comienzo del otoño, momento en el que se produce la berrea. En este caso, el mensaje cifrado podría leerse en relación a este hecho, de forma alegórica. En su lectura anual, se vería como una alusión al final del verano y la llegada del otoño, el sol del equinoccio de otoño.

En los ejemplos mencionados, en los que vemos a la cierva precediendo indistintamente al círculo, al caballo o al ciervo, podría tratarse de una evocación de un concepto o incluso algún mito sobre el sol naciente, desempeñando la cierva un papel de nuncia del astro diurno, como Venus.

El bastón perforado evoca, pues, varios conceptos interrelacionados que mantienen entre sí relaciones de oposición o de complementariedad. Por un lado, el aspecto fálico, masculino, lunar, del soporte estaría asociado a la perforación o círculo lunar/solar. Por otro, al subrayar el sentido de la decoración con el tema solar crearía otro sistema de relaciones de oposición con respecto al tema lunar del soporte. Es decir, que el objeto en estos casos citados, obedecería a una doble simbología: lunar del soporte y solar de la decoración. Los diversos temas que se pueden entrelazar mantendrían, en general, relaciones de complementariedad o de oposición. Quedarían plasmados conceptos y mitos referidos a estas cuestiones relativas al sol-luna/verano-invierno. Leroi-Gourhan (1968: 26-27) ya había considerado a ciertos objetos, como los bastones de mando, del género masculino, los cuales podrían tener decoración de tipo masculino, femenino o de ambos sexos, según su sistema de atribuciones en torno al significado sexual de los animales.

Estas cuestiones nos permiten ir aclarando el funcionamiento de los sistemas de codificación utilizados por el hombre paleolítico en torno a ciertas ideas de contenido astral-naturalista. Se aludiría a conceptos o mitos referentes a la oposición y sucesión del día y la noche, del verano y el invierno, así como al ciclo de transformación lunar. Vendría conformado generalmente por la asociación, yuxtaposición o superposición del caballo y el bóvido. A veces, mediante el caballo rodeado por figuras de bóvidos, mamuts o cápridos. Ambos temas se pueden desarrollar varias veces en un santuario, acudiendo frecuentemente al desarrollo a través de díadas, tríadas y tetramorfos, correspondiente con las etapas o fases del recorrido astral.

Resulta adecuado pasar a referir algunos casos que pueden ser considerados como escenas, descriptivas de acciones, evocadoras de rituales efectuados y que entran dentro de la categoría de pictogramas. Según veremos, en algunos de los ejemplos citados, el modo esquemático en que puede ser sugerida una acción hace difícil definir y situar la frontera exacta entre el pictograma y el mitograma.

\section{La unión sagrada}

Laming-Emperaire (1962) consideraba, a partir de ciertas asociaciones del bisonte y la mujer, que podía existir entre ambos elementos una relación de complementariedad entre un elemento masculino y otro femenino, dentro del marco general de la fecundidad. En las mitologías, el toro o el bisonte, como principio masculino, es el primer ser creado por la Diosa, a la que fecunda. Es el elemento masculino que junto a la Diosa da origen a las cosas. En el plano celeste se explica porque designa al aspecto masculino de la luna que fecunda a la Diosa y la transforma en "Diosa grávida" o luna llena. Este misterio que vemos plasmado por primera vez en el Paleolítico Superior explica diversas tradiciones posteriores, por ejemplo, el papel fecundador del macho cabrío en la mitología vasca (OrtizOsés 1996: 53, 81, 84, 96), del toro en el Mediterráneo, del oso en los relatos árticos o del perro en las mitologías americanas (Mc Lachlan 2006: 292), donde se narra su unión sexual con una mujer. Se advierte en la transformación de Zeus en toro para poder seducir a Europa, o en el Minotauro, hijo de Pasifae (La Diosa) $\mathrm{y}$ de un enorme toro. Todas estas versiones se hacen eco del tema de la unión sagrada entre la Diosa y su hijo/esposo: el toro lunar. En el contexto paleolítico, 


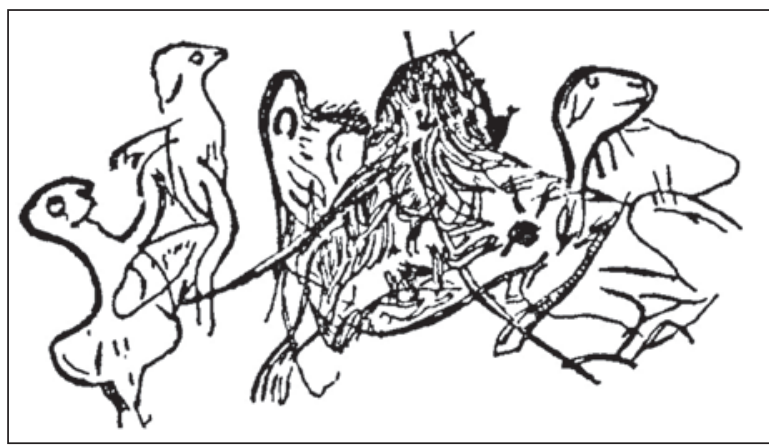

Figura 7. Los Casares (Riba de Saelices, Guadalajara, España). Escena de dos antropomorfos, varón y hembra que realizan una unión sexual ante un mamut y una máscara-mamut, uno de cuyos colmillos apunta al pubis femenino (Según J. Cabré).

la luna vendría representada a través del toro, cáprido, mamut, rinoceronte u oso. El cuerno o el colmillo es el elemento alusivo de la luna. El oso se vincula, similarmente, a la oscuridad, la noche y el invierno.

En lo que respecta a este tipo de asociaciones, es conocido un caso, en el que resulta más explícito y detallado el enunciado de la acción desarrollada. En este sentido, un claro ejemplo de hierogamia se reproduciría en la cueva de Los Casares, en Guadalajara (Fig. 7), según apreció F. Jordá. En una escena una mujer practica la cópula con un antropomorfo masculino, al mismo tiempo que un mamut introduce su colmillo en el pubis femenino. F. Jordá lo interpreta como la representación de un ritual, un matrimonio sacro, una hierogamia (Jordá 1978; 1983). Hay que destacar que en el arte de esta misma cavidad se registran escenas relativas a ritos de purificación acuáticos, lo cual evidencia un conjunto de prácticas chamánicas, efectuadas en los santuarios rupestres.

Según la definición de Leroi-Gourhan, este conjunto encajaría dentro de lo que entiende como un pictograma. Creemos que esta escena sería similar a otro conjunto de La Magdeleine (Tarn) que presenta la agrupación de un bisonte y una mujer tumbada, o de SaintCirq (Dordoña) (Fig. 8), en el panel de fondo, en el que se advierte un triángulo, el cual sería una reproducción sintética de la Diosa, situándose junto a ella un antropomorfo itifálico, y al otro lado un bisonte, pues se trataría de una yuxtaposición significativa. El acto que es plasmado con más detalle en Los Casares, pasaría a registrarse de forma más sumaria, mediante la yuxtaposición de personajes y signos. Probablemente quedaría expresado, a través de un lenguaje más sumario, una acción similar a la señalada en Los Casares. Podemos citar otro ejemplo, en Pech-Merle (Fig. 9). En el plafón de la gran sala, se puede observar la superposición de una figura femenina y un mamut, en el que destaca el sentido fálico de la trompa del animal. En este caso se acudiría simplemente a la superposición para transmitir un mensaje que creemos de contenido similar.

Los casos referidos harían alusión a la unión sagrada con la Diosa. En dos de los paneles aludidos, sería efectuada por el chamán, como alter ego del principio lunar fecundador: bisonte, toro, cáprido, oso o mamut. Este tipo de rituales, conocidos en Próximo Oriente (Frankfort 1988), son también llevados a la práctica por chamanes siberianos, dentro de lo que son los ritos de consagración (Sternberg 1925; Eliade 1982: 7380). La Diosa es la dadora de los poderes mágicos, la

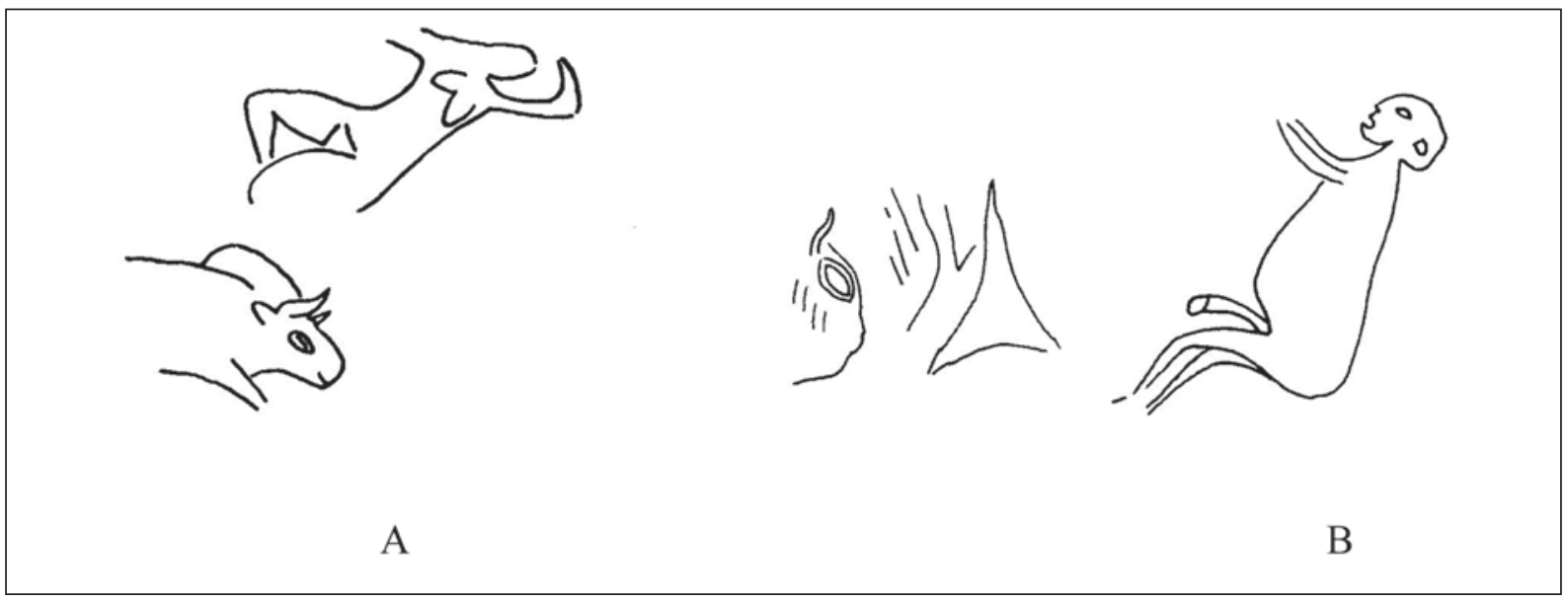

Figura 8. A. Mujer tumbada y bisonte. La Magdeleine, Tarn. B. Antropomorfo, triángulo femenino y bisonte. Saint-Cirq, Dordoña (Según Leroi-Gourhan). 


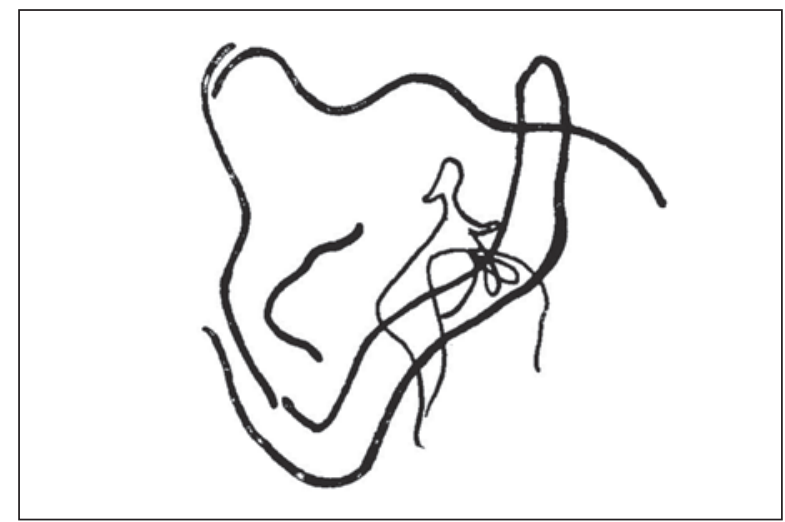

Figura 9. Antropomorfo femenino y mamut. Pech-Merle (Lot) (Según Lemozi).

garante de la transmisión de los poderes divinos al chamán. Este sería uno de los episodios que se integrarían dentro de los ritos de consagración del chamán, escenificados en las cavernas-santuarios. Lo que de forma más explícita es narrado en Los Casares, es más sumariamente expresado en La Magdeleine o en Saint-Cirq, para pasar a ser evocado a través de la superposición en Pech-Merle. Tenemos ejemplos diversos, utilizados para codificar el mensaje. Por otra parte, la caverna es concebida como manifestación de la Gran Madre, por lo que el propio ritual consiste en una bajada o introducción en el ámbito de la Diosa, en el útero femenino.

Creemos que el artista paleolítico al superponer figuras o yuxtaponerlas establecía relaciones de significación entre los diversos elementos interrelacionados. No se esforzaba por expresar explícitamente los hechos míticos, sobre todo porque el contenido del arte, aunque acude a formas naturalistas, es de contenido simbólico y alegórico.

\section{El encuentro mítico del hombre y el bisonte/toro/oso}

Se reconoce en diversos paneles de cavidades y en objetos mobiliares un conjunto de escenas que tratan del enfrentamiento de un antropomorfo con un toro o bisonte (Fig. 10). En otros dos casos se trata de un enfrentamiento con un oso (Fig. 11). En Lascaux, en el fondo de un pozo natural profundo o cripta, bajo el nivel principal del suelo de la caverna, un lugar de lo más difícil y peligroso de alcanzar, se identifica un gran bisonte, atravesado por una lanza, ante un hombre tumbado. El individuo lleva una máscara de pájaro y tiene manos como de pájaro, a su lado hay una vara que lleva sobre el regatón la imagen de un pájaro. La escena fue interpretada como un momento de trance chamánico (Lommel 1967: 128). El personaje fue interpretado como un chamán, ya que el atuendo y la transformación en pájaro son elementos característicos del chamanismo desde Siberia a Norteamérica (Campbell 1991: 343-347). En su día, Breuil la había interpretado simplemente como una escena narrativa de caza.

Además de esta "escena del pozo" de Lascaux, existen tres versiones parietales más y una versión mobiliar del mismo tema del encuentro del hombre y el bisonte/toro. Las versiones parietales son las de Lascaux, Villars, Levanzo y un bloque con bajorrelieves que constituía un friso, en el caso de Roc-de-Sers. La versión mobiliar, grabada en asta de reno, de LaugerieBasse (Dordoña), es del Magdaleniense Medio. Cronológicamente se adscriben al Solutrense y al Magdaleniense. Leroi-Gourhan vio en ellas un tema mítico (Leroi-Gourhan 1984a: 537-538); las considera englobadas dentro de un grupo en el que el hombre parece sometido a prueba y aparece normalmente vencido (Leroi-Gourhan 1968: 72; 1984a: 538). Les aplicaba la denominación de pictogramas, por lo descriptivas de la acción. Escenas similares tienen por protagonistas un antropomorfo y un oso. Se reproducen en la placa de piedra de la cueva de Péchialet (Dordoña) (Fig. 11), en la que dos humanos están enfrentados a un oso y en un rodete de hueso de Mas d'Azil (Ariège), con un personaje masculino en lucha con un oso. En la versión de Lascaux (Fig. 10a), el antropomorfo tiene cabeza de pájaro, en los otros casos parece tener algún tipo de máscara. En Péchialet (Fig. 11a), las siluetas antropomorfas parecen evocar pájaros. Sin duda, la repetición de este tipo de escenas indica que debe tratarse de algún mito y de un ritual.

En el campo de la mitología se puede reconocer como el mito del héroe solar o pájaro solar que se enfrenta al guardián del Más Allá y de la noche, normalmente concebido bajo la figura de un toro, oso, jaguar, etc. En numerosos casos es conocido a través de su formulación primitiva, del mito del robo del fuego (Frazer 1986; Cencillo 1998: 142-148).

Por primera vez en la Historia del Arte y las Religiones vemos plasmado este tema del encuentro o enfrentamiento del hombre y el toro, tema iniciático ampliamente documentado en la Historia de las Religiones y que incluso subsiste en poblaciones primitivas. Muchas sociedades cazadoras del ártico y América del Norte lo conocen en su versión del encuentro iniciático del hombre y el oso. El oso es un espíritu superior o entidad sobrenatural, ligado al chamán. En los mitos se cuenta que tiene oculto al fuego, al sol, o que es causante del frío 

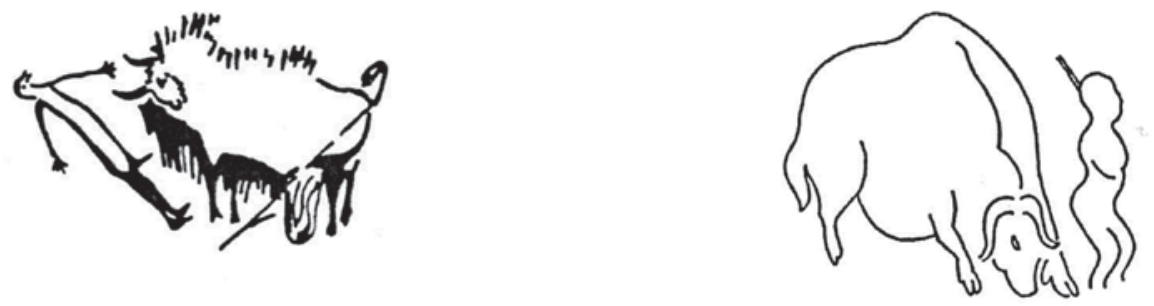

A

B

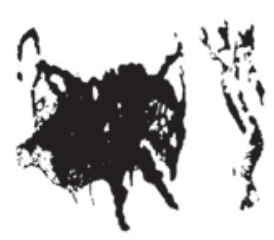

3

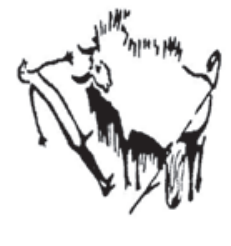

4
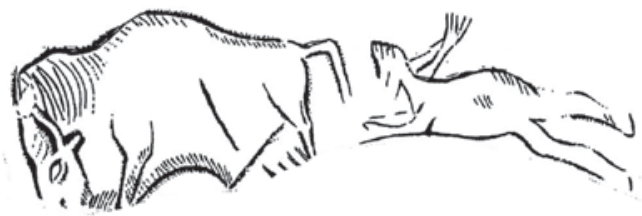

$\mathrm{D}$
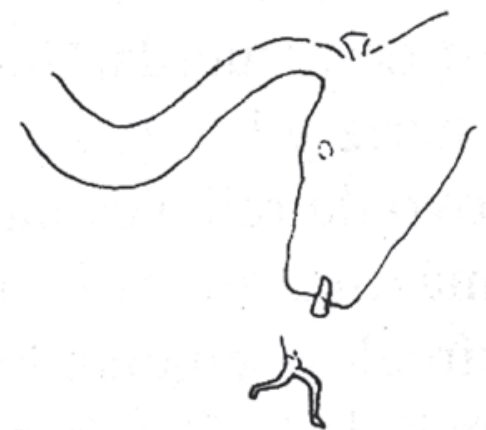

E

Figura 10. El tema del enfrentamiento del hombre y el toro/bisonte: A. Lascaux, Dordoña, Francia. B. Roc-de-Sers, Charente, Francia. C. Villars, Dordoña, Francia. D. Laugerie-Basse, Dordoña, Francia. E. Levanzo, Sicilia, Italia (Según Leroi-Gourhan, A-C; según G. Tosello y J.P. Duhard, D; según Graziosi, E ).

del invierno. Es misión del chamán o el pájaro recuperar el fuego del sol. Entre los kaska, una primitiva tribu athapascana, que mora en las laderas árticas de las montañas Rocosas, en el extremo más alejado de la Columbia Británica, el mito cuenta que el fuego estaba en poder de un Oso. Un pájaro entró en su madriguera y consiguió robarle el fuego (Campbell 1991: 316). La historia adquiere sentido en un contexto chamánico, en el rito iniciático de la búsqueda de la luz por parte del chamán, oculta en el inframundo. Uno de los atributos principales del chamán es la búsqueda de la luz, que finalmente encontrará tras descender a la caverna, a la noche original del seno materno, a la oscuridad primordial (Bonnefoy 2002: 194-195). En América y Siberia se conocen muchas tradiciones de estos encuentros entre el chamán $\mathrm{y}$ un oso o un perro (animales normalmente ligados a 


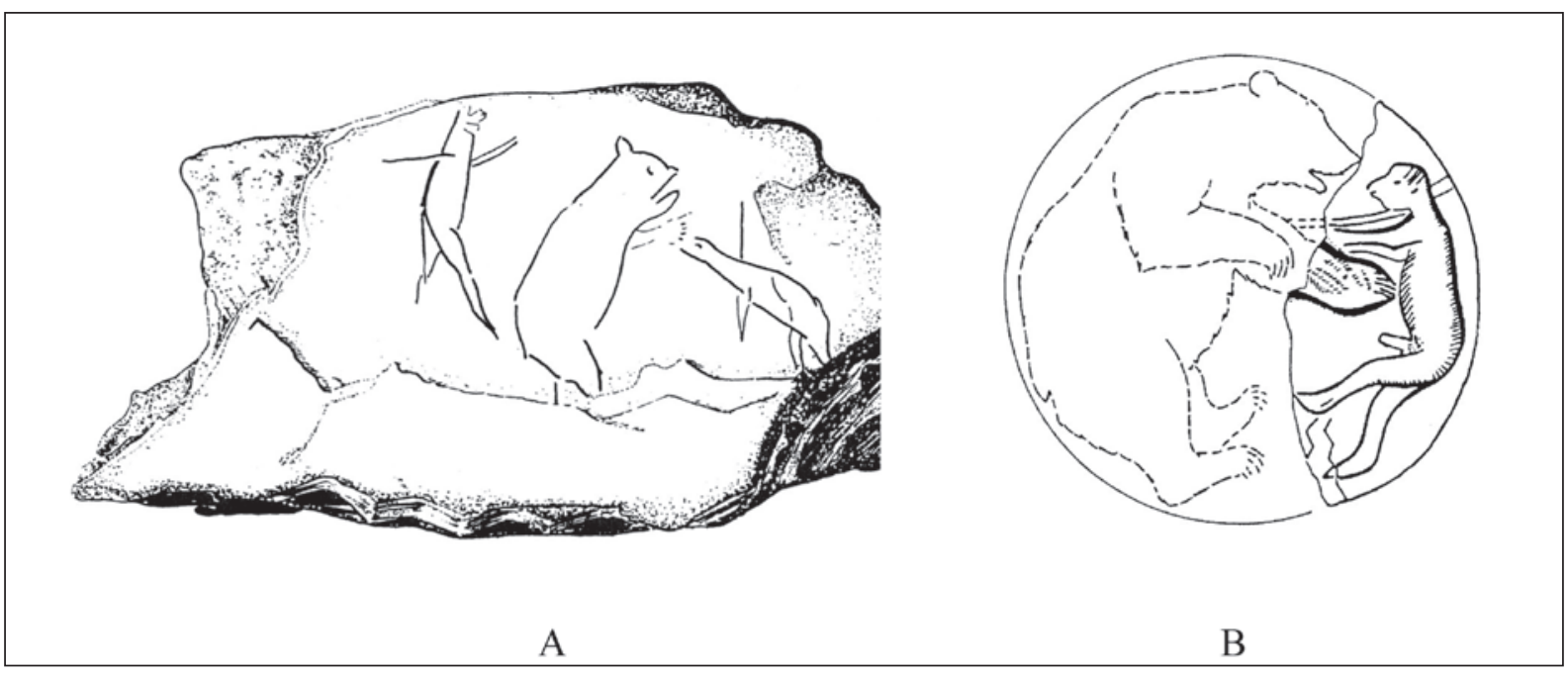

Figura 11. El tema del enfrentamiento del hombre y el oso: A. Péchialet, Dordoña, Francia. B. Mas d'Azil, Ariège, Francia (Según G. Tosello).

la luna, en Siberia y el Ártico), en ritos vinculados a la consagración del chamán (Eliade 1982: 54, 64, 160-170, 235). El chamán es el encargado de robar la luz del sol perdida en las profundidades del inframundo y oculta por el espíritu o divinidad de la noche. El chamán en estos relatos adquiere la forma de un pájaro, tal y como vemos en el arte paleolítico.

Los mitos sobre el pájaro están muy extendidos por el Ártico, Siberia y América. Existe una interrelación de hechos míticos: el motivo del pájaro se encuentra asociado con la acción de consecución de la luz o el fuego (Zimmerman 2002: 123; 2003: 43). Para los chukchi, los itelmen, los koryak y yupik del noreste de Siberia, así como para los distintos grupos de inuit de Alaska, Canadá y Groenlandia adquiere la forma de un cuervo, personaje mitológico de central importancia. Es el antecesor primigenio que trajo a los hombres la luz del día (Cotterell 2004: 136-137). Los esquimales inupiaq tienen historias orales que cuentan cómo fue creado al principio el Hombre Cuervo por el primer chamán. El Hombre Cuervo arponea a una ballena. Posteriormente crea la luz del día y los primeros hombres.

Entre las variantes o permutaciones que sufre el mito es muy típico el motivo del oso, como guardián del fuego (Campbell 1991: 316; Frazer 1986: 141-142). El pájaro tiene un encuentro con el oso o debe dar caza al oso, puesto que éste tiene oculto el fuego/la luz/ el sol/ el verano. El personaje logra robar el fuego y lo devuelve a la humanidad. Es un claro mito sobre la dialéctica de la luz y la oscuridad, en el que la figura del oso, ballena, bisonte o cualquiera de las permutaciones, representaría al espíritu o divinidad de la noche y la luna. El logro es la recuperación del fuego oculto por la noche, perdido en la oscuridad.

En el arte paleolítico podemos observar constataciones de esta interconexión entre el motivo del pájaro, el bisonte y el oso. En la plaqueta de arenisca de Le Puy de Lacan (Corrèze) (Fig. 12a) vemos yuxtapuestos el tema del bisonte y un pájaro (Leroi-Gourhan 1968: 305). En la plaqueta de hueso grabado de Château des Eyzies (Dordoña) (Fig. 12b) se advierte una curiosa escena, similar a la del colgante de Raymonden (Dordoña) (Leroi-Gourhan 1968: 297; Sanchidrián 2005: 191-192), en la que se representa la parte anterior de un bisonte y una hilera de personajes con siluetas parecidas a pájaros y objetos al hombro. En la cripta de Lascaux, el personaje que se halla tumbado junto al bisonte tiene cabeza de pájaro; en la placa grabada de Péchialet, junto al oso, se encuentran personajes que recuerdan en su morfología a pájaros.

El conjunto total de estas representaciones que aluden a antropomorfos o antropomorfos-pájaros/pájaros y bisontes, toros u osos, las consideramos de carácter mítico y ritual. Es muy probable que pudieran conllevar una acción de caza o sacrificatoria, paralelamente, como se desprendería de la lectura inmediata de la mayoría de estas escenas, pero lo que sí creemos es que los hechos narrados se escenificarían ritualmente en los santuarios, como parte de los ritos consagratorios del chamán, reproduciendo ideas míticas. Las formas y acciones de la caza se relacionarían con ideas "trascendentes" que expresarían la alternancia y oposición del sol y la luna, la luz y oscuridad, de la vida y la muerte, 


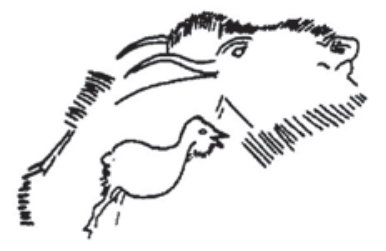

A

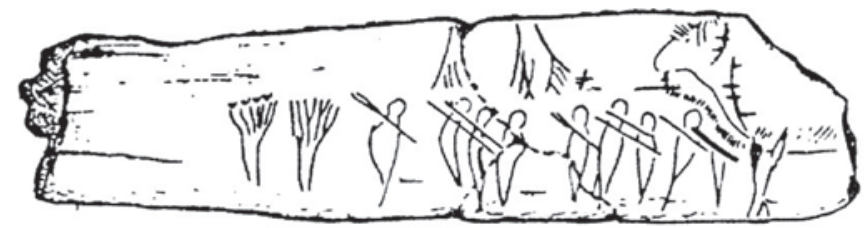

$\mathrm{B}$

Figura 12. A. Plaqueta de arenisca de Le Puy de Lacan (Corrèze). Bisonte y pájaro (Según Leroi-Gourhan). B. Plaqueta de hueso grabado de Château des Eyzies (Dordoña). Personajes-pájaro en fila con objeto a los hombros y parte delantera de un bisonte (Según G. Tosello y J.P. Duhard).

propia de los fenómenos celestes, como base y explicación de la vida, modelo de acción a imitar. En última instancia es un mito y rito de renacimiento, del triunfo de la luz y la vida sobre la oscuridad y la muerte; la muerte concebida como germen de vida. Mostramos algunos hechos que señalan el carácter simbólico del tema y su escenificación en los santuarios.

Sobre el significado que debieron poseer en el marco de la dialéctica luz-oscuridad se pueden señalar los siguientes aspectos. Por una parte, hemos de subrayar la ubicación de algunas de estas escenas, como la de la cripta de Lascaux, en un santuario, en una zona de difícil acceso, acompañando a un personaje con máscara de pájaro, propia más bien de algún rito iniciático. Habría que añadir que el tema, rítmicamente reproducido en el santuario de Lascaux, es el de la oposición del caballo (solar) y el bóvido (lunar) (Lacalle 1998), por lo cual, este tipo de representación se encuadraría en la mitología general reproducida en este santuario sobre la oposición entre el principio diurno y el nocturno. Por otra parte, la escena de Laugerie-Basse, la encontramos formando parte de la decoración de un objeto mobiliar, cuya otra cara se encuentra decorada con un caballo. Es decir, aquí tenemos una constatación de que el tema es concebido dentro del marco simbólico de oposición dualística de los temas: caballo-bisonte, en este caso, entendidos desde la dialéctica luz-oscuridad, sol-luna, verano-invierno. Para Leroi-Gourhan, es clara la intencionalidad simbólica de estas escenas (Leroi-Gourhan 1968: 304).

En cuanto a la escenificación de estos ritos, apuntan a su constatación, la escultura acéla del oso de Montespan (Alto Garona), junto al que apareció un cráneo de oso, probablemente por formar parte de un ritual de este tipo, en el que se reproducía la acción de matar o cortar la cabeza al oso. La propia escena de Lascaux aparece en un contexto propio de la ejecución de un ritual. Con este tipo de acciones hemos de relacionar e incluir en este grupo ciertas escenas, repetidas en varias cavidades, en las que se distinguen dos rostros antropomorfos afrontados (Font-de-Gaume, Rouffignac), definidos como máscaras humanas frente a frente (Leroi-Gourhan 1983; 1984b: 185). Uno de ellos es siempre de mayor tamaño y de aspecto "grotesco". En el caso de Rouffignac, la máscara de mayor tamaño parece tener algo así como un cuerno. En Font-de-Gaume es similar a la cabeza de un mamut, posiblemente una máscara-mamut. Las evidencias señalan a la representación de un encuentro iniciático. Por tanto, parece tratarse de ejemplos claros de escenificación del ritual, del encuentro entre el individuo, chamán, frente a un personaje enmascarado, representativo del animal que es considerado espíritu o guardián de la noche.

El hecho es que este tema es ampliamente conocido en época histórica, manteniendo un eslabón en la etapa megalítica, donde volvemos a encontrar el mismo motivo. Al observar los enlaces y evolución en épocas posteriores se esclarece el desarrollo de este arcaico mito y ritual que en las cavernas paleolíticas relacionamos con los ritos propios de la consagración chamánica y que en momentos posteriores localizamos en el mismo ámbito europeo. Así lo podemos observar en el Tesoro de Atreo (Fig. 13a), formando parte de la decoración del muro de entrada a la cámara. Del mismo modo se puede distinguir la figura del toro, como guardián de la entrada del sepulcro, en la cueva funeraria de Anghelu Ruju (Cerdeña), o situado sobre puertas en hipogeos de Cerdeña (Gimbutas 1996: 269, 285).

Podemos ver al toro, junto al hacha y la espiral-laberinto en el sepulcro megalítico de Gavrinis, en Bretaña, como rito de tránsito al más allá, donde se libra la batalla entre el sol y la deidad de la noche. En el sepulcro megalítico es habitual encontrar el tema de la Diosa-serpiente, el hacha, la doble hacha, la espiral-laberinto, el toro. El toro o la Diosa se sitúan en la cámara funeraria o en la zona 


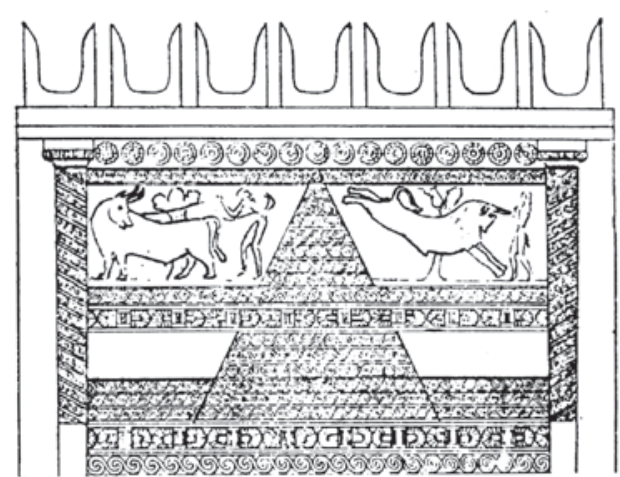

A

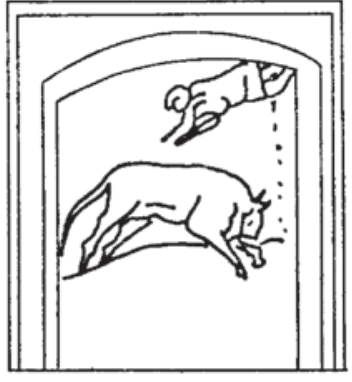

B

Figura 13. A. Decoración de la zona superior del muro de entrada a la cámara del Tholos de Atreo (Micenas) (Según Clark y Higgins). B. Cipo romano pintado de Thina, Túnez. Un toro lanza por alto a un bestiarius (Según S. Reinach).

de acceso a ésta, en posición opuesta a la entrada del sol naciente por el corredor. La decoración funciona a modo de mitograma (Lacalle 1997, 1999, 2008). El sol vence al toro lunar/vence o fecunda a la Diosa- serpiente, lo cual es equivalente del triunfo de la vida y la luz sobre la muerte y la oscuridad. Actúa como carta mítica de legitimidad de la casta social privilegiada que se considera por sus orígenes emparentada con la divinidad y con los antepasados fundadores (Lacalle 1997, 1999, 2000, 2008). La élite enterrada en los dólmenes debía ritualmente enfrentarse al guardián para poder renacer como cuerpo celeste. Las decoraciones iluminadas por la luz del orto solar, así como la espiral colocada con frecuencia en el umbral de acceso, son un símbolo de ese renacimiento. Esto explica la abundancia de soliformes y otros motivos astrales en la decoración de las sepulturas dolménicas, junto a la representación de antropomorfos (como símbolos de heroización), asimilando los difuntos a los astros, dada la concepción celeste del Más Allá, en el que esperan renacer estos individuos. Costumbres análogas se pueden documentar entre los mayas. Cuando un jefe divino moría, debía ser preparado para vencer a los dioses en combate y de esta manera renacer como cuerpo celeste.

La continuidad en el tiempo de este mito y ritual de remotos orígenes se puede ejemplificar en otros casos (Fig. 13b). Durante la Protohistoria se advierte en la orientación ritual de los altares en forma de piel de toro de la Península Ibérica, del I milenio a. C. (Escacena 2007). Las derivaciones históricas de este mito las hallamos en los ritos mitraicos, con Mitra como vencedor del toro en la caverna, en la figura de diversos héroes fundadores, como Teseo, vencedor del Minotauro en el laberinto (morada de la doble hacha), en Gilgamesh, como vencedor del Toro del Cielo, Hércules capturando al toro de Creta, padre del Minotauro, como uno de sus doce trabajos, o Hércules robando el rebaño a Gerión, personaje de tres cabezas y dios de los toros.

La evocación del mito la podemos contemplar por primera vez en el arte paleolítico, en diversos casos en el contexto de la caverna-santuario, bajo la forma de escenas, dentro de lo que son los ritos de consagración del chamán, en su bajada al inframundo y su posterior ascenso celeste tras vencer a los poderes de la noche y la oscuridad. Eso sí, teniendo en cuenta que las escenas son reflejo de un mito.

\section{Dispositivos de signos}

Conviene citar algunos casos en los que se detecta cierto ordenamiento con respecto a la disposición de signos en las cavernas. Se aprecia una disposición lineal en algunos conjuntos, como ocurre en paneles de la cueva de Nerja, Navarro (Málaga) (Sanchidrián 2005: 273-274), así como en la Pasiega (Cantabria) (Breuil y otros 1913: 36) o en la cueva Sombre (Ardèche) (VV.AA. 1984: 608) (Fig. 14-15).

En la cueva de La Pasiega (Breuil y otros 1913: 36; Ripoll 1998: 571-572) (Fig. 15a), en un lugar elevado y muy visible se encuentra un grupo de signos de color rojo-violeta, la llamada "inscripción”, que sus descubridores calificaron de cabalísticos. En el registro superior, a la izquierda, hay un signo con un eje central, dos dobles puertas y líneas verticales, sobre una plataforma de dos rayas horizontales. A la derecha, se identifican dos plantas de pies humanos unidos por una 
Figura 14. Dispositivos de signos en torno a figuras animales. A. Cueva Navarro B.

Nerja (Según Sanchidrián).

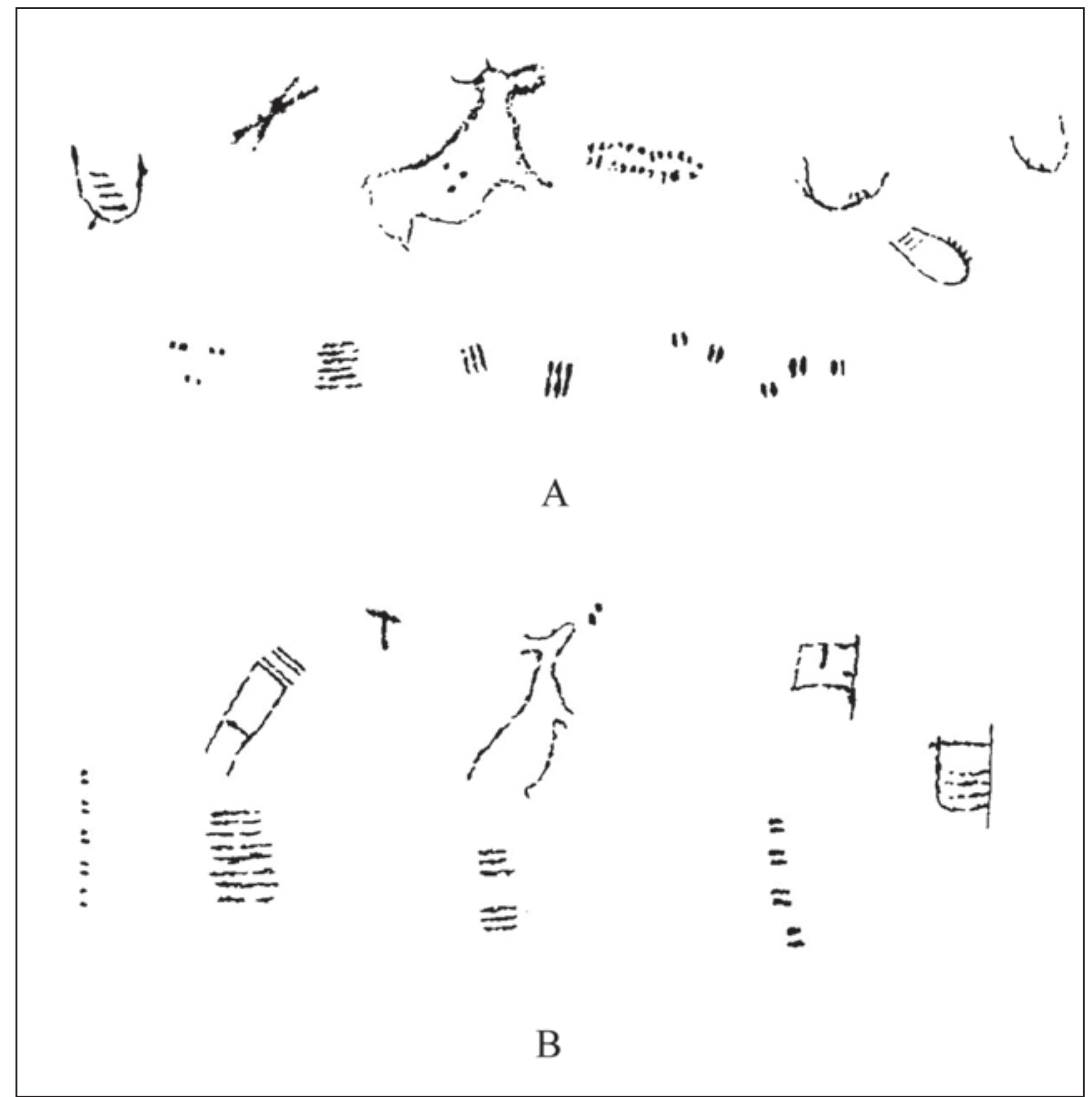

A

Figura 15. Dispositivos de signos: A. Cueva de La Pasiega (Cantabria) (Según Leroi-Gourhan); B. Cueva Sombre (Ardèche) (Según J. Combier y P. Ayroles)

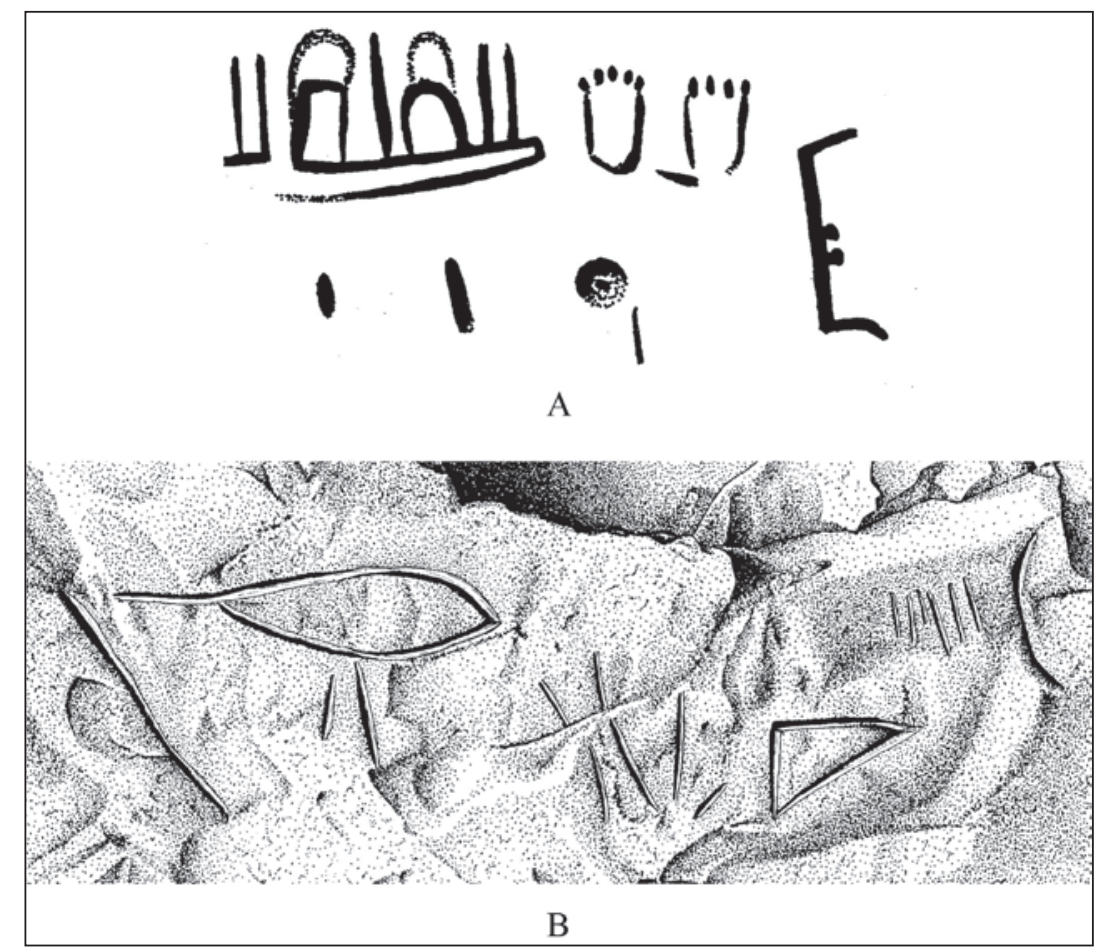


raya. En la zona inferior se advierten puntos o trazos irregularmente dispuestos y a la derecha un signo alfabetiforme parecido a una E mayúscula con el trazo medio geminado.

Es difícil establecer el alcance de lo que significan estos dispositivos ordenados de signos, en lo que respecta a la codificación de los mensajes y el tipo de sistema de transmisión del mensaje ante el que nos encontramos. Quizás, en el caso de Nerja y cueva Navarro, puedan ser notaciones de tipo calendárico. Puntos y líneas han sido habitualmente signos empleados para codificar números. Además, en el contexto de una mitología lunisolar haría bastante probable esta posibilidad.

¿Qué alcance tiene la constatación de estos dispositivos de signos en cuanto a la información transmitida y al tipo de sistema de transmisión del mensaje utilizado? ¿Se podría definir como algún tipo de escritura este tipo de disposición secuencial?

\section{CONCLUSIONES}

Hemos tratado de demostrar cómo las representaciones figurativas que constituyen el arte paleolítico adquieren sentido desde una perspectiva simbólica. Siguiendo este punto de vista, los conceptos de ideograma y de mitograma son los que nos parecen más adecuados para aplicar al arte paleolítico, como sistema más general de codificación de la información, pero que no excluye y de hecho puede acudir al uso de otros sistemas en aquellos casos que se requiera.

Los elementos que conforman el arte paleolítico, tanto figurativos, como ideomorfos, desempeñarían una función emblemática. Lo más habitual es encontrar imágenes que se asocien, yuxtaponen o superponen, pero no se llega a articularlas de manera explícita y narrativa, por lo que se hace particularmente difícil poner en evidencia su organización. En este contexto es fundamental el papel que adquiere la disposición de figuras en la cavidad, considerando que los hechos adquieren una lógica al contemplarlos en un contexto de una mitología de base naturalista-astral, con la caverna y la montaña como símbolo de la Diosa Madre. Hemos propuesto, pues, una alternativa de lectura que explicaría las vías de codificación del mensaje utilizadas por el hombre paleolítico. Creemos que existen abundantes fundamentos que permiten sostener esta interpretación. Desde esta propuesta enunciada, consideramos que el sistema mitográfico debió aludir al comportamiento cíclico de los astros en su manifestación animal, cuyo origen y muerte se relacionaría con la Diosa Madre como caverna, cuyo nacimiento y ocaso son referidos con respecto a la Madre Tierra. Es necesario que los astros prosigan sus ciclos, de ello depende la vida, el bienestar humano, la abundancia y la reproducción humana y animal.

No es descartable que futuros descubrimientos alumbren más sobre ciertos dispositivos ordenados de signos, cuyo alcance sobre la codificación de la información transmitida y el tipo de sistema del que se trata habrá que evaluar cuando dispongamos de un mayor conocimiento al respecto.

\section{BIBLIOGRAFÍA}

APELlÁNIZ, J. M. (1991): Modelo de análisis de la autoría en el arte figurativo del Paleolítico. Universidad de Deusto, Bilbao.

BARANDIARÁN, I. (2003): Grupos homoespecificos en el imaginario mobiliar magdaleniense. Universidad del País Vasco, Vitoria.

BARANDIARÁN, I. (2006): Imágenes y adornos en el arte portátil paleolítico. Ariel Prehistoria, Barcelona.

BLÁZQUEZ, J.M. (1962): "Venaciones y juegos de toros en la Antigüedad", Zephyrus XII: 47-65.

BONNEFOY, Y. (Dir.) (2002): Las mitologías de América, África y Oceanía. Diccionario de las mitologías, Vol. VI. Ediciones Destino, Barcelona.

BREUIL, H; OBERMAIER, H. y ALCALDE DEL RÍO, H. (1913): La Pasiega à Puente Viesgo. Institut de Paléontologie Humaine, Mónaco.

BREUIL, H. (1952): Quatre cents siècles d'art parietal. Les cavernes ornées de l'Age du Renne. Montignac.

CABRERA VALDÉS, V. y GIMÉNEZ LA ROSA, M. (1989): "Arte mueble paleolítico en la cornisa cantábrica”, Revista de Arqueología 103: 12-24.

CAMPBELL, J. (1991): Las máscaras de Dios. Mitología primitiva. Alianza, Madrid.

CATALÁN, D. (2006): "Mitología del extremo sur del continente americano", Mitologías amerindias: 235-283. Trotta, Madrid.

CENCILlO, L. (1998): Los Mitos. Sus mundos y su verdad. Biblioteca de Autores Cristianos, Madrid.

COTTERELL, A. (comp.) (2004): Enciclopedia de Mitología Universal. Panagon, Barcelona.

ELIADE, M. (1982): El chamanismo y las técnicas arcaicas del éxtasis. Fondo de Cultura Económica, México.

ESCACENA, J.L. (2007): "El dios que resucita: claves de un mito en su primer viaje a Occidente", $A c$ tas del IV Congreso Español de Antiguo Oriente Próximo: 615-652. Zaragoza.

FRAZER, J. G. (1986): Mitos sobre el origen del fuego. Alta Fulla, Barcelona. 
GIMBUTAS, M. (1996): El lenguaje de la Diosa. GEA, Oviedo.

HAUSER, A. (1982): Teorías del Arte. Guadarrama, Barcelona.

JORDÁ CERDA, F. (1978): "Los estilos en el arte parietal del Magdaleniense cantábrico", Curso de Arte Rupestre Paleolítico: 79-130.

JORDÁ CERDA, F. (1983): "El mamut en el arte paleolítico peninsular y la hierogamia de Los Casares", $\mathrm{Ho}$ menaje al Profesor Martín Almagro Basch: 265-272.

LACALLE, R. (1996) "El símbolo de la mano en el arte paleolítico", Zephyrus XLIX: 273-279.

LACALLE, R. (1997): El arte megalítico en el Mediodía Hispánico. Tesis de Linciatura (inédita), Universidad de Sevilla.

LACALLE, R. (1998): "Sobre el significado de algunas composiciones del arte paleolítico", Zephyrus LI: 265-276.

LACALLE, R. (1999): "Relaciones entre el arte y la mitología megalítica", Gallaecia 18: 37-53.

LACALLE, R. (2000): "El Megalitismo en el SO de Andalucía: un indicador de jerarquización social", Madrider Mitteilungen 41: 54-70.

LACALLE, R. (2008): Arte, mito y religión en la Prehistoria. Tesis Doctoral, Universidad de Sevilla.

LAMING-EMPERAIRE, A. (1962): La signification de l'art rupestre paléolithique. Méthode et applications. París.

LEROI-GOURHAN, A. (1968): Prehistoria del Arte occidental. Barcelona.

LEROI-GOURHAN, A. (1983): "Les entites imaginaires. Esquisse d'une recherche sur les monstres parietaux paléolithiques", Homenaje al Profesor Martín Almagro Basch: 251-263.
LEROI-GOURHAN, A. (1984a): Simbolos, Artes y Creencias de la Prehistoria. Istmo, Madrid.

LEROI-GOURHAN, A. (1984b): Arte y grafismo en la Europa prehistórica. Istmo, Madrid.

LOMMEL, A. (1967): Shamanism. The beginnings of art. Mac Graw-Hill Book Company, New York.

LOWIE, R. H. (1983): Religiones primitivas. Alianza, Madrid.

Mc LACHLAN, C.A. (2006): "El perro en las mitologías cheroqui y amerindia", Mitologías amerindias: 235-283. Trotta, Madrid.

MÜLLER, F.M. (1988): Mitología comparada. Edicomunicación S.A., Barcelona.

ORTIZ-OSÉS, A. (1996): La Diosa Madre. Interpretación desde la mitología vasca. Trotta, Madrid.

ORTIZ RESCANIERE, A. (edit.) (2006): Mitologías amerindias. Trotta, Madrid.

RIPOLL, E. (1998): "El arte paleolítico I", Prehistoria. Tomo I. UNED, Madrid.

SANCHIDRIÁN, J.L. (2005): Manual de arte prehistórico. Ariel Prehistoria, Barcelona.

STERNBERG, L. J. (1925): "Divine election in primitive religion", Congrès Internacional des Américanistes, sesión XX, parte 2: 475-512. Göteborg.

UCKO, P.J. y ROSENFELD, A. (1972): “Anthropomorphic representations in paleolithic art", Santander Symposium: 149-211. Madrid.

VVAA (1984): L'Art des cavernes: Atlas de grottes ornées paléolithiques francaises. Ministére de la Culture. Paris.

ZIMMERMAN, L. J. (2002): Indios norteamericanos. Evergreen.

ZIMMERMAN, L. J. (2003): Indios americanos. Las primeras naciones. Ediciones Jaguar, Madrid.

FECHA DE ENTRADA: 30-03-2009

FECHA DE ACEPTACIÓN: 16-01-2010 